\title{
KARAKTERISTIK TEPUNG KECAMBAH KACANG NAGARA (Vigna unguiculata ssp Cylindrica) PADA SKALA KECIL DAN SCALE UP
}

\section{CHARACTERISTICS OF NAGARA BEAN (Vigna unguiculata ssp Cylindrica) SPROUT FLOUR ON SMALL SCALE AND SCALE UP}

\author{
Rini Hustiany ${ }^{1 *}$, Noor Winda Wati ${ }^{1)}$, Emy Rahmawati ${ }^{2)}$, Alia Rahmi ${ }^{1)}$, Susi ${ }^{1)}$ \\ ${ }^{1)}$ Jurusan Teknologi Industri Pertanian, Universitas Lambung Mangkurat, Banjarbaru \\ Jl. Jend. A. Yani KM 36 Banjarbaru 70714 \\ Email: rini.hustiany@ulm.ac.id \\ 2) Jurusan Agribisnis, Universitas Lambung Mangkurat, Banjarbaru
}

Makalah: Diterima 22 Desember 2018; Diperbaiki 24 Oktober 2019; Disetujui 10 November 2019

\begin{abstract}
South Kalimantan's pre-eminent cowpea, namely Nagara beans, needs to be improved, one of them being sprout flour. The purpose of this study was to (1) analyze the chemical and physicochemical properties of Nagara bean sprout flour on a small scale; (2) determining the best soaking and germination time on a small scale; and (3) comparing the chemical properties of Nagara bean sprout flour between small scale and scale up. The method used is making Nagara bean sprout on a small scale with an amount of $500 \mathrm{~g}$, while on a scale up making sprout with an amount of 3000 g. Making sprouts on a small scale soaking for 12, 18, and 24 hours and germination for 24, 36, 42 and 48 hours. The germination for scale up is done with the best soaking and germination time of small-scale results, namely soaking for 12 hours and germination for 48 hours. The result is that soaking time only affects protein and carbohydrate content, whereas the interaction between soaking and germination time only affects the protein content of Nagara bean sprout flour. The best Nagara bean sprout flour is produced with a 12 hours soaking time and 48 hours germination time. Changes in the scale of the process of germination of Nagara bean sprout flour from small scale to scale up caused a decrease in levels of ash, protein and vitamin $C$ content and an increase in levels of fat, carbohydrates, $\mathrm{Fe}, \mathrm{Ca}$, and vitamin $\mathrm{E}$ content.
\end{abstract}

Keywords : Nagara bean, sprout, flour, small scale, scale up

\section{ABSTRAK}

Kacang tunggak unggulan Kalimantan Selatan, yaitu kacang Nagara, perlu ditingkatkan pemanfaatannya, salah satunya menjadi tepung kecambah. Tujuan penelitian ini adalah untuk (1) menganalisis sifat kimia dan fisikokimia tepung kecambah kacang Nagara pada skala kecil; (2) menentukan lama perendaman dan lama perkecambahan terbaik pada skala kecil; dan (3) membandingkan sifat kimia tepung kecambah kacang Nagara antara skala kecil dan scale up. Metode yang digunakan adalah membuat kecambah kacang Nagara pada skala kecil dengan jumlah $500 \mathrm{~g}$, sedangan pada scale up pembuatan kecambah dengan jumlah $3000 \mathrm{~g}$. Pembuatan kecambah pada skala kecil dilakukan perendaman selama 12, 18, dan 24 jam dan dilakukan perkecambahan selama 24, 36, 42 dan 48 jam. Adapun perkecambahan untuk scale up dilakukan dengan lama prendaman dan perkecambahan terbaik hasil skala kecil, yaitu perendaman selama 12 jam dan perkecambahan selama 48 jam. Hasilnya adalah lama perendaman hanya mempengaruhi kadar protein dan karbohidrat, sedangkan interaksi antara lama perendaman dan lama perkecambahan hanya mempengaruhi kadar protein tepung kecambah kacang Nagara. Tepung kecambah kacang Nagara terbaik dihasilkan dengan lama perendaman 12 jam dam lama perkecambahan 48 jam. Perubahan skala proses perkecambahan tepung kecambah kacang Nagara dari skala kecil ke scale up menyebabkan terjadinya penurunan kadar abu, protein dan vitamin $\mathrm{C}$ dan terjadinya peningkatan kadar lemak, karbohidrat, $\mathrm{Fe}, \mathrm{Ca}$, dan vitamin $\mathrm{E}$.

Kata Kunci : kacang Nagara, kecambah, tepung, skala kecil, scale up

\section{PENDAHULUAN}

Kacang tunggak yang tumbuh secara endemik di daerah rawa lebak di kecamatan Daha Utara dan Selatan, kabupaten Hulu Sungai Selatan, Kalimantan Selatan dikenal dengan nama kacang Nagara. Pada musim kemarau, yaitu pada saat tanah kering dan tidak terendam dengan air, maka kacang Nagara ditanam dan diproduksi. Kacang Nagara hampir sama dengan kacang tunggak yang lain, akan tetapi ada perbedaannya, yaitu kacang Nagara berukuran kecil dan kulitnya terlihat sedikit keriput.

Kacang Nagara mempunyai kekurangan pada saat diolah, yaitu sangat berbau asam dan getir. Menurut Hustiany (2015) bau asam dan getir pada kacang Nagara disebabkan tingginya kandungan karbohidrat. Bau asam dan getir dapat dikurangi dengan cara dikecambahkan, karena pada saat perkecambahan terjadi perombakan makromolekul menjadi mikromolekul. Selain itu, dengan adanya 
perkecambahan, maka bagian hilum dan kulit kacang dapat dilepaskan dan dibuang pada saat perkecambahan. Apabila bagian hilum dan kulit kacang dilepaskan, maka dapat menurunkan kadar lemak kacang Nagara (Hustiany et al., 2016) dan dapat mengurangi bau pada kacang.

Perkecambahan pada kacang Nagara juga bertujuan untuk menghasilkan olahan pangan dengan daya cerna yang tinggi. Pada saat ini cukup banyak bahan olahan pangan yang berbasiskan kecambah, seperti minuman fungsional tinggi serat dan protein berbasiskan kecambah kacang kedelai (Aminah, 2010), kacang komak (Saputro et al., 2015), kacang tolo (Saputro et al., 2015), penambahan kecambah kacang hijau untuk bakso ayam (Hairunnisa et al., 2016), susu kecambah kacang hijau (Wea et al., 2014), dan MPASI berbasiskan tepung kecambah kacang tunggak (Ismayanti dan Harijono, 2015).

Proses perkecambahan dipengaruhi oleh suhu, cahaya, oksigen, air, waktu perendaman, dan waktu perkecambahan. Waktu perendaman terbaik adalah 12 jam (Anita, 2009) atau 12 sampai 24 (Salunkhe et al., 1985) yang berfungsi untuk imbibisi air ke dalam biji. Adapun waktu perkecambahan selama 24 sampai 48 jam pada kacang komak (Anita, 2009).

Sebagian besar penelitian kecambah, selain kecambah kacang hijau dan kedelai, pada saat ini masih skala kecil. Kondisi perkecambahan pada skala kecil berbeda dengan kondisi perkecambahan pada scale up. Pada kondisi perkecambahan yang di scale up, maka jumlah kacang yang digunakan lebih banyak, ketebalan penumpukan kacang lebih besar, distribusi oksigen dan cahaya juga terbatas terutama pada bagian dalam tumpukan kacang. Oleh karena itu perlu diketahui karakteristik kecambah yang telah di scale up.

Agar kecambah yang digunakan dapat diaplikasikan lebih luas, maka kecambah yang dihasilkan diolah dulu menjadi tepung. Yasa et al. (2009) menyebutkan bahwa penggunaan tepung kecambah pada makanan sapihan tradisional dapat meningkatkan kadar protein rata-rata sebesar $34 \%$. Tepung kecambah yang biasa digunakan untuk makanan sapihan biasanya berasal dari kacang hijau, kacang kedelai dan kacang merah.

Berdasarkan hal tersebut, maka tujuan penelitian ini adalah untuk (1) menganalisis sifat kimia dan fisikokimia tepung kecambah kacang Nagara pada skala kecil; (2) menentukan lama perendaman dan lama perkecambahan terbaik tepung kecambah kacang Nagara pada skala kecil; dan (3) membandingkan sifat kimia tepung kecambah kacang Nagara antara skala kecil dan scale up.

\section{Bahan}

\section{BAHAN DAN METODE}

Kacang Nagara dari kecamatan Daha, $\mathrm{HCl}$, $\mathrm{H}_{2} \mathrm{SO}_{4}, \mathrm{HNO}_{3}$, asam asetat, asam metafosfat, thiourea, dinitrofenilhidrazin, $\mathrm{KOH}$, etanol, heksan, natrium sulfat anhidrat, metanol, isopropanol, $\mathrm{BaSO}_{4}$, aquabidest, fluor $\mathrm{A}$, amino butiric acid, alpha amino butiric acid, AccQ-fluor borat, buffer na-fosfat, dinitrosalisilat, MES-TRIS, standar asam askorbat, standar $\alpha$-tokoferol, standar maltosa, standar asam amino, $\alpha$-amilase, amiloglukosidase, dan protease.

\section{Metode Penelitian}

Tahap pertama adalah pembuatan tepung kecambah kacang Nagara pada skala kecil dengan berbagai lama perendaman dan perkecambahan. Perendaman dilakukan dengan lama 12, 18 dan 24 jam. Adapun perkecambahan dilakukan dengan lama 24, 30, 36, 42, dan 48 jam. Penelitian ini dilaksanakan dengan 2 kali ulangan, sehingga diperoleh 30 satuan percobaan. Ulangan yang dikerjakan sebagai kelompok dalam analisis data.

Adapun tahap kedua adalah pembuatan tepung kecambah kacang Nagara dengan di scale up. Lama perendaman dan perkecambahan pada tahapan scale up adalah lama perendaman dan perkecambahan terbaik hasil penelitian tahap pertama, yaitu dengan lama perendaman 12 jam dan lama perkecambahan 48 jam. Pembuatan tepung kecambah kacang Nagara pada scale up dilakukan dengan 2 kali ulangan.

\section{Pembuatan Kecambah dan Tepung Kecambah Kacang Nagara pada Skala Kecil \\ Kacang Nagara terlebih dahulu disortasi} dari yang cacat dan benda-benda asing. Kacang Nagara yang digunakan masih banyak yang biji kacangnya kosong dan ringan dan belah, serta masih banyak kotoran berupa sisa polong, ranting, dan batu. Bahan-bahan kotoran ini akan mengganggu selama proses perkecambahan.

Kacang Nagara selanjutnya dicuci dengan air dan direndam dengan air dengan perbandingan antara kacang Nagara dan air adalah 1 : 3. Kacang Nagara yang digunakan sebanyak $500 \mathrm{~g}$. Perendaman dilakukan selama 12, 18, dan 24 jam. Setelah dilakukan perendaman, air rendaman dibuang dan ditiriskan. Selanjutnya kacang Nagara dibungkus dengan menggunakan daun pisang, agar kacang Nagara masih tetap lembab selama proses perkecambahan. Proses perkecambahan dilakukan selama 24, 30, 36, 42, dan 48 jam.

Setelah selesai perkecambahan, kecambah kacang Nagara dibersihkan bagian kulitnya dan dikeringkan pada suhu $50^{\circ} \mathrm{C}$. Setelah kering, kecambah dihaluskan sampai 80 mesh.

\section{Pembuatan Tepung Kecambah Kacang Nagara pada Scale Up}

Kacang Nagara terlebih dahulu disortasi dari kacang Nagara yang cacat dan kotoran. Kemudian kacang Nagara dicuci dan direndam dengan perbandingan antara kacang Nagara dan air adalah $1: 3$. Lama perendaman dan perkecambahan 
pada scale up adalah 12 jam dan 48 jam yang merupakan hasil terbaik dari penelitian pembuatan kecambah kacang Nagara pada skala kecil. Pada scale up ini, jumlah kacang Nagara yang digunakan adalah $3 \mathrm{~kg}$ atau 6 kali lebih banyak dari skala kecil.

Kacang Nagara yang sudah direndam dan ditiriskan, selanjutnya dimasukkan ke dalam keranjang plastik berlubang kecil dan ditutup dengan plastik hitam. Selama proses perkecambahan, secara periodik kacang Nagara dipercikkan dengan sedikit air. Setelah perkecambahan 48 jam, kecambah kacang Nagara dibuang bagian kulitnya dan dikeringkan pada suhu $60-70^{\circ} \mathrm{C}$. Kecambah yang sudah kering selanjutnya dihaluskan sampai 80 mesh.

\section{Pengamatan}

Penelitian tahap pertama untuk tepung kecambah kacang Nagara pada skala kecil dianalisis berupa analisis proksimat, derajat putih, densitas kamba (Muchtadi, 1993), indeks penyerapan air, dan indeks kelarutan air. Hasil terbaik dari tepung kecambah kacang Nagara kemudian dilanjutkan dengan analisis vitamin C (Apriyantono et al., 1989), vitamin E (Ball, 1988; AOAC 971.30, 1972), kadar $\mathrm{Fe}$ (metode AAS (Atomic Absorption Spectrometry)), dan kadar Ca (metode AAS).

Adapun tepung kecambah kacang Nagara pada scale up untuk penelitian tahap kedua, maka tepung kecambah kacang Nagara dianalisis berupa analisis proksimat, vitamin $\mathrm{C}$, vitamin $\mathrm{E}$, kadar $\mathrm{Fe}$ (metode AAS (Atomic Absorption Spectrometry)), dan kadar $\mathrm{Ca}$ (metode AAS). Selain itu juga ditambahkan analisis total gula (metode Anthrone), komposisi asam amino (metode UPLC (Ultra Performance Liquid Chromatography) (Nollet, 1996; Waters Corporation, 2012), daya cerna pati (metode enzimatis) (Prangdimurti et al., 2013), serta kadar serat pangan larut dan tidak larut (metode enzimatis) (AOAC Method 991.43, 1995) terhadap tepung kacang Nagara hasil scale up.

\section{Derajat Putih (Anita, 2009)}

Alat yang digunakan adalah whiteness meter Kett Electric Laboratory tipe C-100-3. Tepung kecambah kacang Nagara dimasukkan ke dalam tempat sampel dan dibaca derajat putihnya. Kemudian standar $\mathrm{BaSO}_{4}$ juga dimasukkan ke dalam tempat sampel dan dibaca derajat putihnya. Hasil derajat putih tepung kecambah kacang Nagara dibandingkan dengan standar $\mathrm{BaSO}_{4}$. Nilai derajat putih $\mathrm{BaSO}_{4}$ adalah 110 .

$$
\text { Derajat Putih }=\frac{\text { Derajat putih sampel x } 100 \%}{110}
$$

\section{Indeks Penyerapan Air (IPA) (Muchtadi, 1993)}

Tepung kecambah kacang Nagara sebanyak 1 g dimasukkan ke dalam tabung sentrifusa dan ditambahkan $10 \mathrm{~mL}$ aquades. Campuran diaduk dengan menggunakan vortex sampai semua tercampur merata. Campuran disentrifugasi dengan kecepatan 2000 rpm selama 15 menit pada suhu kamar. Bagian supernatannya dipisahkan dari endapannya. Bagian endapan hasil sentrifusa kemudian ditimbang.

$$
\mathrm{IPA}=\frac{(b-a) \times 100 \%}{m s \times(1-k a)}
$$

Keterangan :

a = berat sampel awal + berat tabung sentrifusa $(\mathrm{g})$

$\mathrm{b}=$ berat endapan + berat tabung sentrifusa $(\mathrm{g})$

$\mathrm{ms}=$ berat sampel awal $(\mathrm{g})$

$\mathrm{ka}=$ kadar air

Indeks Kelarutan dalam Air (IKA) (Muchtadi, 1993) Sebanyak $2 \mathrm{~mL}$ supernatan hasil pengukuran IPA dimasukkan ke dalam cawan aluminium yang telah ditimbang berat awalnya. Supernatan tepung kecambah kacang Nagara dikeringkan pada suhu $110^{\circ} \mathrm{C}$ sampai semua air menguap. Apabila supernatan sudah kering, maka cawan didinginkan dan ditimbang berat supernatannya.

$$
\mathrm{IKA}=\frac{\text { berat supernatan }(\mathrm{g})}{\text { berat sampel }(1-\text { kadar air })} \times 100 \%
$$

\section{Analisis Data}

Peneltian tahap pertama dianalisis Analysis of Variance (ANOVA) dengan rancangan acak kelompok dua faktor pada $\alpha=5 \%$. Apabila hasil perhitungan ANOVA berpengaruh, maka dilanjutkan dengan uji DMRT (Duncan Multiple Range Test) pada $\alpha=5 \%$ menggunakan SPSS versi 24. Adapun untuk tahap kedua hanya dilakukan analisis deskriptif.

\section{HASIL DAN PEMBAHASAN}

\section{Kecambah Kacang Nagara}

Proses perkecambahan suatu kacangkacangan dapat dipengaruhi oleh lama perendaman dan lama perkecambahan. Perendaman bertujuan untuk mempermudah proses perkecambahan.

Perkecambahan pada kacang Nagara dapat mencapai $70-80 \%$. Masih ada kacang Nagara yang tidak mengalami perkecambahan disebabkan mutu kacangnya rendah dan kacang kekurangan oksigen, sehingga sulit untuk berespirasi. Pada kacang yang dikecambahkan akan terjadi perubahan morfologi, fisiologi, dan biokimia. Agar permanfaatan kecambah kacang Nagara dapat dikembangkan lebih luas, maka kecambah kacang Nagara dijadikan tepung kecambah kacang Nagara.

\section{Analisis Proksimat \\ Kadar air tepung kecambah kacang Nagara untuk berbagai lama perendaman dan}


perkecambahan tidak berbeda, yaitu berkisar antara 7,57 sampai 10,51 \% (Tabel 1). Artinya lama perendaman dan perkecambahan yang berbeda tidak mempengaruhi molekul air untuk keluar pada bahan pada saat pengeringan.

Adapun kadar abu tepung kecambah kacang Nagara berkisar antara 3,37 sampai 4,69 \%bk (Tabel 2). Kadar abu tepung kecambah kacang Nagara untuk berbagai lama perendaman dan perkecambahan tidak berbeda.

Lama perendaman dan perkecambahan tidak mengurangi kadar abu yang ada di dalam tepung kecambah kacang Nagara. Kadar abu tepung kecambah kacang Nagara tidak berbeda dengan tepung kacang Nagara tanpa kulit $(3,04 \%)$ dan tepung kacang Nagara yang disangrai (3,03 \%) (Hustiany et al., 2016). Menurut Pranoto et al. (1990) pada saat perkecambahan berlangsung, terjadi perombakan beberapa senyawa mineral menjadi ion-ion fosfat, magnesium, kalsium, dan kalium yang selanjutnya ditranslokasikan ke titik tumbuh. Jadi mineral yang ada di dalam kacang Nagara hanya berubah bentuk dan berpindah tempat, tetapi tidak mengurangi jumlah mineral selama proses perkecambahan.
Akan tetapi apabila kacang Nagara difermentasi untuk dihasilkan menjadi tempe, maka terjadi penurunan kadar abu, hal ini diduga disebabkan proses pencucian, perendaman dan perebusan sebelum proses fermentasi, mampu untuk melarutkan mineral pada kacang Nagara (Hustiany et al., 2016). Penurunan kadar abu setelah proses fermentasi juga terjadi pada barley. Sebelum dilakukan fermentasi, maka kadar abu barley adalah 2,16\% (Khokhar et al., 2010). Setelah dilakukan fermentasi, maka kadar abu barley terfermentasi menjadi 0,9 \% (Alminger dan Eklund-Jonsson, 2008).

Tepung kecambah kacang Nagara mengandung lemak berkisar antara 1,75 sampai 3,34 $\%$ bk (Tabel 3). Lama perendaman dan perkecambahan tidak berpengaruh terhadap kadar lemak tepung kecambah kacang Nagara. Kadar lemak ini tidak berbeda dengan kadar lemak kacang Nagara tanpa kulit $(2,28 \%)$ dan kacang Nagara sangrai $(2,50 \%)$ (Hustiany et al., 2016). Artinya selama proses perkecambahan tidak terjadi proses metabolisme lemak secara signifikan. Sekalipun terjadi metabolisme lemak, maka metabolismenya hanya sedikit.

Tabel 1. Kadar air tepung kecambah kacang Nagara (\%)*

\begin{tabular}{ccccc}
\hline Lama Perkecambahan & \multicolumn{3}{c}{ Lama Perendaman (jam) } & Rata-Rata \\
\cline { 2 - 4 } (jam) & $\mathbf{1 2}$ & $\mathbf{1 8}$ & $\mathbf{2 4}$ & \\
\hline 24 & $9,42 \pm 0,34$ & $8,12 \pm 2,28$ & $8,76 \pm 3,64$ & $8,77 \pm 2,09$ \\
30 & $9,23 \pm 0,39$ & $8,26 \pm 2,63$ & $7,57 \pm 3,26$ & $8,35 \pm 2,09$ \\
36 & $10,06 \pm 2,04$ & $7.76 \pm 2,22$ & $9,14 \pm 0,87$ & $8,99 \pm 1,71$ \\
42 & $9,20 \pm 0,18$ & $8,61 \pm 3,00$ & $9,38 \pm 1,63$ & $9,06 \pm 1,60$ \\
48 & $10,51 \pm 0,59$ & $8,78 \pm 3,79$ & $8,63 \pm 2,56$ & $9,31 \pm 2,31$ \\
Rata-rata & $9,68 \pm 0,71$ & $8,31 \pm 2,78$ & $8,70 \pm 2,39$ & \\
\hline
\end{tabular}

*Rata-rata dari dua kali ulangan

$* \mathrm{P}>0,05$

Tabel 2. Kadar abu tepung kecambah kacang Nagara (\% bk)*

\begin{tabular}{|c|c|c|c|c|}
\hline \multirow{2}{*}{$\begin{array}{c}\text { Lama Perkecambahan } \\
\text { (jam) }\end{array}$} & \multicolumn{3}{|c|}{ Lama Perendaman (jam) } & \multirow[t]{2}{*}{ Rata-Rata } \\
\hline & 12 & 18 & 24 & \\
\hline 24 & $4,26 \pm 0,11$ & $3,69 \pm 0,26$ & $3,63 \pm 0,13$ & $3,86 \pm 0,17$ \\
\hline 30 & $4,30 \pm 0,26$ & $3,55 \pm 0,57$ & $3,67 \pm 0,06$ & $3,84 \pm 0,30$ \\
\hline 36 & $4,43 \pm 0,66$ & $3,58 \pm 0,36$ & $3,37 \pm 0,11$ & $3,79 \pm 0,38$ \\
\hline 42 & $4,55 \pm 0,51$ & $3,47 \pm 0,38$ & $3,45 \pm 0,08$ & $3,82 \pm 0,32$ \\
\hline 48 & $4,69 \pm 0,43$ & $3,66 \pm 0,17$ & $3,39 \pm 0,14$ & $3,91 \pm 0,25$ \\
\hline Rata-rata & $4,45 \pm 0,40$ & $3,59 \pm 0,35$ & $3,50 \pm 0,10$ & \\
\hline
\end{tabular}

*Rata-rata dari dua kali ulangan

$* \mathrm{P}>0,05$

Tabel 3. Kadar lemak tepung kecambah kacang Nagara (\% bk)*

\begin{tabular}{ccccc}
\hline Lama & \multicolumn{3}{c}{ Lama Perendaman (jam) } & Rata-Rata \\
\cline { 2 - 4 } Perkecambahan (jam) & $\mathbf{1 2}$ & $\mathbf{1 8}$ & $\mathbf{2 4}$ & \\
\hline 24 & $2,07 \pm 1,39$ & $1,75 \pm 0,85$ & $3,04 \pm 1,89$ & $2,29 \pm 1,38$ \\
30 & $2,30 \pm 1,15$ & $1,77 \pm 0,23$ & $2,71 \pm 1,95$ & $2,26 \pm 1,11$ \\
36 & $2,24 \pm 1,06$ & $1,94 \pm 0,42$ & $3,34 \pm 2,75$ & $2,51 \pm 1,41$ \\
42 & $2,64 \pm 0,95$ & $1,93 \pm 0,78$ & $3,26 \pm 2,06$ & $2,61 \pm 1,26$ \\
48 & $2,49 \pm 1,05$ & $1,93 \pm 0,07$ & $3,20 \pm 2,38$ & $2,54 \pm 1,17$ \\
Rata-rata & $2,35 \pm 1,12$ & $1,86 \pm 0,47$ & $3,11 \pm 2,21$ & \\
\hline
\end{tabular}

\footnotetext{
*Rata-rata dari dua kali ulangan
}

$* \mathrm{P}>0,05$ 
Adapun untuk kadar protein, maka kadar protein tepung kecambah kacang Nagara berkisar antara 24,48 sampai $31,06 \%$ bk (Tabel 4). Kadar protein tepung kecambah kacang Nagara lebih besar dibandingkan dengan tepung kacang Nagara tanpa kulit $(24,16 \%)$ dan tepung kacang Nagara sangrai $(18,12 \%)$ (Hustiany et al., 2016). Artinya adanya proses perkecambahan meningkatkan kandungan protein yang ada di dalam tepung kecambah kacang Nagara.

Lama perendaman berpengaruh terhadap kadar protein tepung kecambah kacang Nagara. Semakin lama perendaman kacang Nagara, maka semakin menurun kadar protein tepung kecambah kacang Nagara. Hal ini disebabkan karena perendaman dapat melarutkan protein yang ada di dalam kacang Nagara. Terutama protein-protein yang tersusun dari asam amino yang bersifat polar yang mudah larut di dalam air, seperti asam aspartat, asam glutamat, serin, arginin, treonin, sistein, histidin, dan lisin. Menurut Hustiany dan Mustikasari (2010) dan Windrati (2010) pada kacang Nagara dan kacang koro banyak mengandung asam aspartat dan asam glutamat. Dengan demikian perendaman kacang Nagara yang semakin lama menyebabkan protein kacang Nagara terlarut dalam air rendaman.

Antara lama perendaman dengan lama perkecambahan pada permbuatan kecambah kacang Nagara ada interaksi. Semakin lama proses perkecambahan dengan waktu perendaman yang semakin pendek, maka kadar protein tepung kecambah kacang Nagara semakin meningkat.
Menurut Utomo (2002), hal ini disebabkan selama proses perkecambahan terjadi pembentukan hormon tumbuh, yaitu giberallic acid, yang menstimulir kegiatan enzim-enzim. Enzim-enzim ini adalah protein. Hal inilah menyebabkan kadar protein semakin tinggi dengan semakin lama proses perkecambahan.

Kadar protein tertinggi dihasilkan dari proses perkecambahan 48 jam dan perendaman selama 12 jam, yaitu sebesar 31,06 \% bk. Hal ini senada dengan penelitian Anita (2009) yang menyatakan bahwa perkecambahan kacang komak untuk menghasilkan kadar protein tertinggi adalah selama 30 jam dengan perendaman selama 12 jam. Artinya dengan perendaman yang tidak terlalu lama, yaitu 12 jam, tidak menyebabkan protein banyak yang larut dan protein dapat ditingkatkan dengan adanya perkecambahan.

Adapun untuk kadar karbohidrat, maka terdapat kecenderungan dengan bertambahnya lama perkecambahan, maka semakin menurun kadar karbohidrat yang dihasilkan (Tabel 5). Sebaliknya, terjadi peningkatan karbohidrat dengan semakin lamanya perendaman. Terjadinya peningkatan dan penurunan kadar karbohidrat pada tepung kecambah kacang Nagara, maka disebabkan terjadinya peningkatan dan penurunan kadar protein pada tepung kecambah kacang Nagara dengan kecenderungan yang sama. Karena hanya kadar protein tepung kecambah kacang Nagara yang terpengaruh dengan adanya lama perendaman dan lama perkecambahan pada proses perkecambahan kacang Nagara.

Tabel 4. Kadar protein tepung kecambah kacang Nagara (\% bk)*

\begin{tabular}{|c|c|c|c|c|}
\hline \multirow{2}{*}{$\begin{array}{c}\text { Lama Perkecambahan } \\
(\text { jam })\end{array}$} & \multicolumn{3}{|c|}{ Lama Perendaman (jam) } & \multirow[t]{2}{*}{ Rata-Rata } \\
\hline & 12 & 18 & 24 & \\
\hline 24 & $28,06 \pm 0,64^{\mathrm{bcd}}$ & $28,57 \pm 1,39^{\text {bcde }}$ & $24,48 \pm 1,02^{\mathrm{a}}$ & $27,04 \pm 1,02$ \\
\hline 30 & $27,51 \pm 2,00^{\mathrm{bcd}}$ & $29,16 \pm 0,25^{\text {cde }}$ & $26,19 \pm 1,18^{\mathrm{ab}}$ & $27,62 \pm 1,14$ \\
\hline 36 & $28,54 \pm 0,36^{\text {bcde }}$ & $27,92 \pm 1,17^{\mathrm{bcd}}$ & $27,11 \pm 0,30^{\mathrm{bc}}$ & $27,86 \pm 0,61$ \\
\hline 42 & $28,12 \pm 0,59^{\mathrm{bcd}}$ & $28,23 \pm 1,87^{b c d}$ & $28,50 \pm 0,59^{\text {bcde }}$ & $28,28 \pm 1,02$ \\
\hline 48 & $31,06 \pm 0,89^{\mathrm{e}}$ & $30,02 \pm 1,74^{\mathrm{de}}$ & $24,49 \pm 0,98^{\mathrm{a}}$ & $28,52 \pm 1,20$ \\
\hline Rata-Rata & $28,66 \pm 0,90^{b}$ & $28,78 \pm 1,28^{b}$ & $26,15 \pm 0,81^{\mathrm{a}}$ & \\
\hline
\end{tabular}

*Rata-rata dari dua kali ulangan

$* \mathrm{P} \leq 0,05$ untuk interaksi antara lama perendaman dan lama perkecambahan serta faktor tunggal dari lama perendaman.

Tabel 5. Kadar karbohidrat tepung kecambah kacang Nagara (\% bk)*

\begin{tabular}{ccccc}
\hline \multirow{2}{*}{$\begin{array}{c}\text { Lama Perkecambahan } \\
\text { (jam) }\end{array}$} & $\mathbf{1 2}$ & $\mathbf{1 8}$ & \multirow{2}{*}{ Rata-Rata } \\
\cline { 2 - 5 } & $56,19 \pm 2,50$ & $57,88 \pm 0,30$ & $60,09 \pm 2,90$ & \\
\hline 24 & $56,67 \pm 0,20$ & $57,26 \pm 2,73$ & $59,86 \pm 2,55$ & $57,93 \pm 1,90$ \\
30 & $54,74 \pm 0,69$ & $58,81 \pm 0,98$ & $57,04 \pm 1,46$ & $56,86 \pm 1,04$ \\
36 & $55,50 \pm 1,87$ & $57,76 \pm 0,72$ & $55,42 \pm 0,24$ & $56,23 \pm 0,94$ \\
42 & $51,26 \pm 1,79$ & $55,62 \pm 2,16$ & $60,30 \pm 1,29$ & $55,73 \pm 1,75$ \\
48 & $54,87 \pm 1,41^{\text {a }}$ & $57,47 \pm 1,38^{\mathrm{b}}$ & $58,54 \pm 1,69^{\mathrm{b}}$ & \\
Rata-rata & & & &
\end{tabular}

*Rata-rata dari dua kali ulangan

$* \mathrm{P} \leq 0,05$ untuk faktor tunggal dari lama perendaman 


\section{Derajat Putih}

Derajat putih tepung kecambah kacang Nagara yang dihasilkan berkisar antara 42,22\% sampai 59,17\% (Tabel 6). Warna tepung kecambah kacang Nagara yang dihasilkan adalah kuning, semakin rendah nilai derajat putih semakin gelap warna yang dihasilkan dan sebaliknya.

Warna kuning pada tepung kecambah kacang Nagara disebabkan terjadinya pencoklatan dengan adanya reaksi Maillard pada saat terjadi pengeringan kecambah kacang Nagara. Pencoklatan ini disebabkan karena selama perendaman dan perkecambahan terjadi perombakan protein menjadi asam amino dan perombakan karbohidrat menjadi gula-gula sederhana. Asam amino dan gula-gula sederhana merupakan prekursor untuk terjadinya reaksi Maillard pada saat pengeringan.

\section{Densitas Kamba}

Densitas kamba suatu tepung adalah untuk melihat besarnya pori-pori diantara partikel-partikel padatan. Semakin besar pori-pori tepung, maka densitasnya kambanya juga akan semakin besar. Penentuan densitas kamba berhubungan dengan seberapa besar volume bahan untuk dapat menempati volume ruang atau wadah tertentu.
Semakin besar ukuran densitas kamba, maka tepung semakin tidak padat.

Densitas kamba produk tepung-tepungan yang diinginkan adalah yang memiliki densitas kamba yang kecil (Anita, 2009) agar mudah dipadatkan, berkisar antara 0,30-0,80 $\mathrm{g} / \mathrm{cm}^{3}$ (Rohmah, 2012). Nilai densitas kamba tepung kecambah kacang Nagara berkisar antara 0,54 $\mathrm{g} / \mathrm{cm}^{3}$ sampai $0,62 \mathrm{~g} / \mathrm{cm}^{3}$ (Tabel 7). Artinya densitas kamba tepung kecambah kacang Nagara adalah kecil dan tepungnya cenderung padat.

\section{Indeks Penyerapan Air}

Tepung dalam penerapannya sebagian besar dicampur dengan air, seperti cookies, roti, biskuit, wafer, dan sebagainya. Jumlah air yang dapat diserap tepung menunjukkan lunak kerasnya produk yang akan dihasilkan. Jumlah air yang terserap oleh tepung secara maksimum dapat ditentukan berdasarkan perhitungan Indeks Penyerapan Air (IPA).

Indeks Penyerapan Air (IPA) tepung kecambah kacang Nagara berkisar antara 166,87\% sampai 236,19\% (Tabel 8). Semakin besar nilai IPA menunjukkan tepung kecambah kacang Nagara semakin mudah menyerap air, sehingga lebih mudah penerapannya di dalam produk pangan.

Tabel 6. Derajat putih tepung kecambah kacang Nagara (\%)*

\begin{tabular}{ccccc}
\hline Lama & \multicolumn{3}{c}{ Lama Perendaman (jam) } & Rata-Rata \\
\cline { 2 - 4 } Perkecambahan (jam) & $\mathbf{1 2}$ & $\mathbf{1 8}$ & $\mathbf{2 4}$ & \\
\hline 24 & $54,07 \pm 6,20$ & $59,17 \pm 2,46$ & $53,40 \pm 2,98$ & $55,55 \pm 3,88$ \\
30 & $53,59 \pm 5,33$ & $54,27 \pm 5,21$ & $54,05 \pm 5,65$ & $53,97 \pm 5,40$ \\
36 & $50,61 \pm 2,42$ & $52,78 \pm 8,73$ & $44,08 \pm 6,86$ & $49,16 \pm 6,00$ \\
42 & $51,16 \pm 0,30$ & $49,81 \pm 7,21$ & $42,22 \pm 13,69$ & $47,73 \pm 7,06$ \\
48 & $46,26 \pm 8,53$ & $48,47 \pm 2,16$ & $47,40 \pm 7,38$ & $47,38 \pm 6,02$ \\
Rata-rata & $51,14 \pm 4,56$ & $52,90 \pm 5,15$ & $48,23 \pm 7,31$ & \\
\hline
\end{tabular}

*Rata-rata dari dua kali ulangan

$* \mathrm{P}>0,05$

Tabel 7. Densitas Kamba tepung kecambah kacang Nagara $\left(\mathrm{g} / \mathrm{cm}^{3}\right)$ *

\begin{tabular}{ccccc}
\hline \multirow{2}{*}{$\begin{array}{c}\text { Lama Pecambahan } \\
\text { jam }\end{array}$} & $\mathbf{1 2}$ & $\mathbf{1 8}$ & Rata-Rata \\
\cline { 2 - 4 } & $0,60 \pm 0,01$ & $0,60 \pm 0,03$ & $\mathbf{2 4}$ & \\
\hline 24 & $0,62 \pm 0,01$ & $0,54 \pm 0,01$ & $0,56 \pm 0,04$ & $0,59 \pm 0,03$ \\
36 & $0,58 \pm 0,05$ & $0,55 \pm 0,00$ & $0,58 \pm 0,05$ & $0,58 \pm 0,02$ \\
42 & $0,60 \pm 0,03$ & $0,56 \pm 0,03$ & $0,59 \pm 0,03$ & $0,56 \pm 0,03$ \\
48 & $0,59 \pm 0,01$ & $0,58 \pm 0,02$ & $0,58 \pm 0,04$ & $0,58 \pm 0,03$ \\
Rata-rata & $0,60 \pm 0,02$ & $0,57 \pm 0,018$ & $0,57 \pm 0,036$ & $0,58 \pm 0,02$ \\
\hline
\end{tabular}

*Rata-rata dari dua kali ulangan

$* \mathrm{P}>0,05$

Tabel 7. Densitas Kamba tepung kecambah kacang Nagara $\left(\mathrm{g} / \mathrm{cm}^{3}\right)^{*}$

\begin{tabular}{ccccc}
\hline Lama Perkecambahan & \multicolumn{3}{c}{ Lama Perendaman (jam) } & Rata-Rata \\
\cline { 2 - 4 } (jam) & $\mathbf{1 2}$ & $\mathbf{1 8}$ & $\mathbf{2 4}$ & \\
\hline 24 & $0,60 \pm 0,01$ & $0,60 \pm 0,03$ & $0,56 \pm 0,04$ & $0,59 \pm 0,03$ \\
36 & $0,62 \pm 0,01$ & $0,54 \pm 0,01$ & $0,58 \pm 0,05$ & $0,58 \pm 0,02$ \\
42 & $0,58 \pm 0,05$ & $0,55 \pm 0,00$ & $0,56 \pm 0,03$ & $0,56 \pm 0,03$ \\
48 & $0,60 \pm 0,03$ & $0,56 \pm 0,03$ & $0,59 \pm 0,03$ & $0,58 \pm 0,03$ \\
Rata-rata & $0,59 \pm 0,01$ & $0,58 \pm 0,02$ & $0,58 \pm 0,04$ & $0,58 \pm 0,02$ \\
\end{tabular}

*Rata-rata dari dua kali ulangan

$* \mathrm{P}>0,05$ 


\section{Indeks Kelarutan Air}

Nilai Indeks Kelarutan Air (IKA) tepung kecambah kacang Nagara yang dihasilkan berkisar antara 1,91\% sampai 5,40 (Tabel 9). Semakin besar nilai IKA menunjukkan bahwa tepung kecambah kacang Nagara semakin mudah larut air, sehingga lebih mudah penerapannya didalam produk pangan

Berdasarkan sifat kimia maupun fisikokimia, maka tepung kecambah kacang Nagara terbaik adalah tepung kecambah yang dihasilkan dengan lama perendaman 12 jam dan lama perkecambahan 48 jam. Hal ini didasarkan bahwa tepung kecambah kacang Nagara yang dihasilkan hanya terjadi perbedaan pada kadar protein dan kadar karbohidrat, sedangkan sifat kimia dan fisikokimia yang lain tidak berbeda untuk semua lama perendaman dan lama perkecambahan. Ditambah lagi, tepung kecambah kacang Nagara dengan lama perendaman 12 jam dan lama perkecambahan 48 jam yang menghasilkan kadar protein tertinggi dan berbeda dengan lama perendaman dan perkecambahan yang lainnya. Dengan dasar ini, maka pembuatan kecambah kacang Nagara yang di scale up menggunakan lama perendaman 12 jam dan lama perkecambahan 48 jam.

\section{Perbandingan Karakteristik Kimia Tepung Kecambah Kacang Nagara Antara Skala Kecil dan Scale Up}

Karakteristik kimia tepung kecambah kacang Nagara pada skala kecil dibandingkan dengan tepung kecambah kacang Nagara hasil scale up
(Tabel 10). Perbandingan ini dilakukan untuk melihat adanya tidaknya perubahan yang terjadi pada tepung kecambah kacang Nagara antara skala kecil dan setelah scale up. Ada beberapa faktor yang mempengaruhi proses perkecambahan pada saat dilakukan scale up dibandingkan dengan skala kecil, yaitu (1) jumlah kacang Nagara dalam satu tempat perkecambahan yang lebih banyak, (2) ketebalan tumpukan kacang Nagara lebih tebal, (3) sirkulasi udara dan gas-gas hasil metabolisme dipengaruhi ketebalan tumpukan kacang Nagara, dan (4) suhu yang berbeda antara bagian atas, bawah, dan dalam dari tumpukan kacang Nagara.

Adanya scale up pada proses pengolahan tepung kecambah kacang Nagara, maka akan menurunkan kadar abu, protein dan vitamin $\mathrm{C}$ dan menaikkan kadar lemak, karbohidrat, kalsium, besi, dan vitamin E, sedangkan kadar air relatif stabil di bawah $12 \%$.

Menurut Pranoto et al. (1990) terjadi perombakan beberapa senyawa mineral menjadi ionion fosfat, magnesium, kalsium, dan kalium yang selanjutnya ditranslokasikan ke titik tumbuh pada saat perkecambahan berlangsung. Oleh karena itu kadar besi dan kalsium meningkat pada saat proses perkecambahan kacang Nagara hasil scale up. Akan tetapi apabila terjadi penurunan kadar abu pada tepung kecambah kacang Nagara hasil scale up, hal ini diduga disebabkan pada saat pencucian dan pelepasan bagian hilum dan kulit kacang Nagara, maka mineral-mineral yang terdapat pada kecambah kacang Nagara ikut terlarut bersama dengan air.

Tabel 9. Indeks kelarutan air tepung kecambah kacang Nagara (\%)*

\begin{tabular}{ccccc}
\hline \multirow{2}{*}{$\begin{array}{c}\text { Lama Perkecambahan } \\
\text { (jam) }\end{array}$} & \multicolumn{3}{c}{ Lama Perendaman (jam) } & Rata-Rata \\
\cline { 2 - 4 } & $\mathbf{1 2}$ & $\mathbf{1 8}$ & $\mathbf{2 4}$ & \\
\hline 24 & $5,40 \pm 0,75$ & $3,24 \pm 0,09$ & $4,23 \pm 2,82$ & $4,29 \pm 1,22$ \\
30 & $3,65 \pm 0,61$ & $2,32 \pm 1,26$ & $3,64 \pm 0,97$ & $3,20 \pm 0,95$ \\
36 & $2,93 \pm 0,12$ & $3,47 \pm 0,37$ & $4,19 \pm 2,61$ & $3,53 \pm 1,03$ \\
42 & $4,23 \pm 0,19$ & $2,75 \pm 1,06$ & $4,54 \pm 1,66$ & $3,84 \pm 0,97$ \\
48 & $3,92 \pm 0,45$ & $1,91 \pm 0,10$ & $3,97 \pm 1,78$ & $3,27 \pm 0,78$ \\
Rata-rata & $4,03 \pm 0,42$ & $2,74 \pm 0,58$ & $4,11 \pm 1,97$ & \\
\hline
\end{tabular}

*Rata-rata dari dua kali ulangan

$* \mathrm{P}>0,05$

Tabel 10. Perbandingan karakteristik kimia tepung kecambah kacang Nagara pada skala kecil dan scale up

\begin{tabular}{lcc}
\hline \multicolumn{1}{c}{ Karakteristik kimia } & Skala Kecil & Scale Up \\
\hline Air (\%) & 10,51 & 9,88 \\
Abu (\% bk) & 4,69 & 3,03 \\
Lemak (\% bk) & 2,49 & 3,17 \\
Protein (\% bk) & 31,06 & 19,83 \\
Karbohidrat (\% bk) & 51,25 & 64,09 \\
Ca (mg/kg) & 27,89 & 42,37 \\
Fe (mg/kg) & 4,19 & 65,56 \\
Vitamin C (mg/kg) & 480 & 261 \\
Vitamin E (mg/kg) & 8,44 & 11,57 \\
\hline
\end{tabular}


Adapun penurunan kadar protein pada tepung kecambah kacang Nagara setelah dilakukan proses scale up disebabkan (1) jumlah kacang Nagara untuk setiap wadah terlalu banyak, akibatnya pada bagian tengah wadah perkecambahan sulit untuk terjadi perkecambahan. Sulitnya perkecambahan pada bagian tengah menyebabkan proses biosintesis juga akan semakin menurun dan enzim-enzim untuk terjadinya biosintesis juga tidak aktif. Hal ini berimbas dengan semakin menurunnya kadar protein pada tepung kecambah kacang Nagara hasil scale up. Sekalipun hanya biosintesis asam askorbat yang terhambat atau terganggu dan biosintesis tocoferol atau vitamin $\mathrm{E}$ semakin meningkat. Akan tetapi biosintesis vitamin E berasal dari metabolisme asam amino (Srinivasan et al., 2019). Akibatnya kadar protein yang terbaca sebagai unsur $\mathrm{N}$ (nitrogen) juga akan menurun.

Sebab ke (2) adalah selama proses perkecambahan dilakukan pemberian air yang relatif banyak. Akibatnya dapat melarutkan protein yang terdapat dalam kecambah kacang Nagara. Apalagi komposisi asam amino dari kacang Nagara terdiri dari asam amino yang bersifat polar yang mudah larut di dalam air, seperti asam glutamat, histidin, serin, arginin, treonin, sistein, asam aspartat, dan lisin (Hustiany dan Mustikasari, 2010). Padahal perkecambahan kacang Nagara diduga lebih baik jangan diberikan air, karena air hasil perendaman diduga sudah cukup untuk proses perkecambahan. Berdasarkan hal ini, maka kadar protein tepung kecambah kacang Nagara hasil scale up lebih rendah dibandingkan kadar protein kecambah skala kecil.

Penurunan kadar protein tepung kecambah kacang Nagara hasil scale up juha disebabkan karena proses pencucian pada saat melepaskan kulit kacang dari kacangnya terlalu lama bersentuhan dengan air. Karena protein dan asam amino yang terdapat pada kacang Nagara bersifat hidrofilik, sehingga mudah sekali untuk larut di dalam air dan akibatnya menurunkan kadar protein tepung kecambah kacang Nagara hasil scale up.

Komposisi asam amino tepung kecambah kacang Nagara hasil scale up banyak mengandung asam glutamat, asam aspartat, leusin, fenilalanin, arginin, dan lisin (Tabel 11). Sebagian besar asam amino yang dikandung tepung kecambah kacang Nagara adalah asam amino polar. Dengan komposisi asam amino yang seperti ini, maka tepung kecambah kacang Nagara cenderung bersifat hidrofilik.

Komposisi asam amino kacang Nagara hampir sama dengan kacang koro pedang yang sudah menjadi protein rich flour (PRF), yaitu asam glutamat sebesar $54,7 \mathrm{mg} / \mathrm{g}$ dan asam aspartat sebesar 45,1 mg/g (Windrati et al., 2010). Apabila dibandingkan dengan tepung defatted kacang Nagara hasil penelitian dari Hustiany dan Mustikasari (2010), maka kandungan asam amino tepung kecambah kacang Nagara menurun, kecuali asam amino serin yang meningkat.
Komposisi asam amino tepung kecambah kacang Nagara berbeda dengan kacang kedelai. Tempe kacang kedelai dengan kandungan arginin yang cukup besar, yaitu $65,8 \mathrm{mg} / \mathrm{g}$ dibandingkan dengan asam glutamat dan asam aspartat yang kandungannya lebih sedikit, yaitu masing-masing $17,4 \mathrm{mg} / \mathrm{g}$ dan $11,3 \mathrm{mg} / \mathrm{g}$ (Utari et al., 2011), sehingga kacang kedelai lebih bersifat hidrofobik.

Tabel 11. Kompisisi asam amino tepung kecambah kacang Nagara hasil scale up

\begin{tabular}{lc}
\hline \multicolumn{1}{c}{$\begin{array}{c}\text { Komposisi Asam } \\
\text { Amino }\end{array}$} & $\begin{array}{c}\text { Jumlah Asam Amino } \\
(\mathbf{m g} / \mathbf{g})\end{array}$ \\
\hline L-triptofan & 2,5 \\
L-sistin & 0,7 \\
L-metionin & 2,8 \\
L-serin & 11,4 \\
L-asam glutamat & 34,6 \\
L-fenilalanin & 16,9 \\
L-isoleusin & 9,6 \\
L-valin & 10,7 \\
L-alanin & 10,4 \\
L-arginin & 14,3 \\
Glisin & 8,9 \\
L-lisin HCL & 13,3 \\
L-asam aspartat & 21,2 \\
L-leusin & 16,9 \\
L-tirosin & 7,7 \\
L-prolin & 8,8 \\
L-threonin & 8,4 \\
L-histidin & 8,2 \\
\hline
\end{tabular}

Penurunan kandungan vitamin $\mathrm{C}$ pada tepung kecambah kacang Nagara hasil scale up disebabkan terganggunya proses biosintesis vitamin C selama proses perkecambahan pada scale up. Biosintesis vitamin C memerlukan cahaya (Shiroma et al., 2019; Zha et al., 2019), dan menurut Yang et al. (2011) biosintesis asam askorbat memerlukan oksigen untuk oksidasi, sehingga enzim oksidasi menjadi aktif untuk melakukan biosintesis vitamin C. Oleh karena itu ada interaksi antara respirasi dan fotosintesis pada saat proses biosintesis vitamin C (Ntagkas et al., 2017).

Dengan adanya cahaya, maka akan memicu perkembagan kloroplas (Shiroma et al., 2019) dan biosintesis vitamin $\mathrm{C}$ terjadinya di kloroplas. Oleh karena itu, apabila pencahayaan kurang, maka biosintesis vitamin $\mathrm{C}$ juga akan menurun. Walaupun proses perkecambahan kacang Nagara dengan cahaya kurang terjadinya pada skala kecil maupun scale up, akan tetapi pada waktu perkecambahan dilakukan scale up, maka tumpukan kacang Nagara semakin tebal. Dengan tumpukan yang semakin tebal, maka semakin menghambat cahaya dan oksigen yang masuk ke dalam proses perkecambahan. Akibatnya proses biosintesis vitamin $\mathrm{C}$ juga akan terganggu. Selain itu, penurunan kadar vitamin $\mathrm{C}$ juga dapat disebabkan pada saat pencucian dan pelepasan bagian hilum dan 
kulit kacang Nagara, maka vitamin C ikut terlarut bersama dengan air.

Apabila biosintesis vitamin $\mathrm{C}$ atau asam askorbat terganggu atau dengan kata lain fotosintesis tidak aktif, maka aktivitas kloroplas bergeser ke arah penyimpanan karbohidrat (Heiber et al., 2014). Menurut Heiber et al. (2014) menyatakan bahwa apabila asam askorbat yang dihasilkan menurun selama proses fotosintesis, maka kadar gula akan meningkat. Hal ini sesuai dengan keadaan tepung kecambah kacang Nagara hasil scale up yang meningkat kadar karbohidratnya (Tabel 10) dan total gula yang relatif tinggi (Tabel 12) dengan menurunnya kadar vitamin $\mathrm{C}$ atau asam askorbatnya (Tabel 10).

Peningkatan kadar lemak pada tepung kecambah kacang Nagara hasil scale up disebabkan lemak berhubungan dengan biosintesis vitamin $\mathrm{E}$. Vitamin E adalah lipid kloroplas (Ji et al., 2016). Apabila terjadi peningkatan biosintesis vitamin E, maka akan meningkat pula lemak yang dihasilkan.

Peningkatan kadar besi pada tepung kecambah kacang Nagara hasil scale up dibandingkan dengan tepung kecambah pada skala kecil disebabkan terjadi penurunan biosintesis asam askorbat akibat kekurangan cahaya dan oksigen. Karena biosintesis asam askorbat terhambat, maka penggunaan $\mathrm{Fe}^{2+}$ juga akan menurun (Smirnoff, 2018). Akibatnya kadar besi akan semakin menurun juga apabila dilihat hanya dari satu sisi biosintesis asam askorbat.

Akan tetapi menurut Kobayashi et al. (2019) Fe merupakan elemen penting dalam berbagai proses seluler, termasuk respirasi, biosintesis klorofil dan fotosintesis. Fe berfungsi sebagai kofaktor untuk enzim. Oleh karena itu, sekalipun biosintesis asam askorbat terhambat, akan tetapi biosintesis vitamin $\mathrm{E}$ atau tocoferol semakin meningkat. Hal ini meningkatkan kadar Fe yang berfungsi sebagai kofaktor enzim pada biosintesis vitamin E.

Adapun peningkatan kadar kalsium (Ca) pada tepung kecambah kacang Nagara hasil scale up disebabkan kalsium adalah elemen yang mempengaruhi biosintesis jasmonat di dalam sel tanaman. Jasmonat adalah salah satu senyawa yang berperanan penting pada proses perkecambahan biji, pembentukan dan pengembangan organ penyimpanan dan penuaan pada tanaman (Wang et al., 2019).

Selain itu, biosintesis kalsium juga dapat ditingkatkan dengan adanya rangsangan secara fisiologis, misalnya pertahanan tanaman terhadap berbagai patogen (Jean dan Ranty, 2013). Apabila kadar kalsium lebih tinggi pada tepung kecambah kacang Nagara hasil scale up, hal ini diduga karena pada proses scale up dengan jumlah kacang Nagara yang semakin banyak, semakin tebal tumpukan kacang Nagara dan jumlah air yang cukup tinggi memudahkan untuk mikrooganisme patogen akan tumbuh selama proses perkecambahan. Akibatnya kacang Nagara yang mengalami proses perkecambahan meningkatkan biosintesis kalsium dengan adanya rangsangan secara fisologis dari mikroorganisme patogen.

Peningkatan kadar vitamin E, karena kondisi perkecambahan yang kurang oksigen dan cahaya merangsang biosintesis vitamin $\mathrm{E}$ atau tocoferol. Vitamin E adalah lipid kloroplas yang terlibat dalam respon tanaman terhadap stres oksidatif (Ji et al., 2016). Berdasarkan hal ini, maka pada kondisi kekurangan oksigen dengan tumpukan kacang yang cukup tebal, maka enzim biosintesis untuk tocoferol semakin aktif dan vitamin E semakin banyak yang terbentuk.

Selain proses biosintesis yang terjadi selama perkecambahan, maka selama proses perkecambahan juga terjadi proses metabolisme. Hal ini dapat dibuktikan bahwa dengan adanya proses perkecambahannya, maka daya cerna pati atau karbohidrat kecambah kacang Nagara akan sangat tinggi, yaitu 80,13 g/100 g (Tabel 12). Serat pangan larut dan serat pangan tidak larut juga cukup tinggi dikandung tepung kecambah kacang Nagara (Tabel 12).

Tabel 12. Total gula, daya cerna pati, serat pangan larut, dan serat pangan tidak larut tepung kecambah kacang Nagara hasil scale up

\begin{tabular}{lc}
\hline \multicolumn{1}{c}{ Karakteristik } & $\begin{array}{c}\text { Tepung Kecambah } \\
\text { Kacang Nagara } \\
\text { Hasil Scale } \text { Up }\end{array}$ \\
\hline Total Gula $(\mathrm{g} / 100 \mathrm{~g})$ & 20,88 \\
Daya Cerna Pati $(\mathrm{g} / 100 \mathrm{~g})$ & 80,13 \\
Serat Pangan Larut $(\%)$ & 6,15 \\
Serat Pangan Tidak Larut & 9,65 \\
$(\%)$ & \\
\hline
\end{tabular}

\section{KESIMPULAN DAN SARAN}

\section{Kesimpulan}

Lama perendaman mempengaruhi kadar protein dan kadar karbohidrat tepung kecambah kacang Nagara pada skala kecil, sedangkan karakteristik kimia dan fisikokimia yang lain tidak berpengaruh. Lama perendaman dan perkecambahan terbaik adalah lama perendaman 12 jam dan lama perkecambahan 48 jam. Adanya proses scale up pada proses pengolahan tepung kecambah kacang Nagara dibandingkan skala kecil, maka akan menurunkan kadar abu, protein dan vitamin $\mathrm{C}$, tetapi akan menaikkan kadar lemak, karbohidrat, $\mathrm{Fe}, \mathrm{Ca}$, dan vitamin $\mathrm{E}$.

\section{Saran}

Saran yang bisa diberikan adalah perlu dilakukan penelitian untuk melakukan lama perendaman yang kurang dari 12 jam, akan tetapi diberikan percikan air secara bertahap selama proses perkecambahan. 


\section{UCAPAN TERIMA KASIH}

Penulis mengucapkan terima kasih kepada Direktorat Jenderal Penguatan Riset dan Pengembangan Kementerian Riset, Teknologi, dan Pendidikan Tinggi yang telah menghibahkan dana penelitian melalui skim penelitian PTUPT (Penelitian Terapan Unggulan Perguruan Tinggi) tahun anggaran 2017.

\section{DAFTAR PUSTAKA}

Alminger M dan Eklund-Jonsson C. 2008. Wholegrain cereal products based on a high-fibre barley or oat genotype lower post-prandial glucose and insulin responses in healthy humans. Eur J Nutr. 47:294-300.

Aminah S. 2010. Potensi Campuran Kecambah Beras Coklat dan Kecambah Kedelai sebagai Minuman Fungsional Tinggi Serat dan Protein. Jurnal Pangan dan Gizi. 1(2) : $27-32$.

Anita S. 2009. Studi sifat fisiko-kimia, sifat fungsional karbohidrat, dan aktivitas antioksidan tepung kecambah kacang komak (Lablab purpurens (L.) sweet). [Skripsi]. Bogor : Institut Pertanian Bogor.

AOAC Method 991.43. 1995. Total, Insoluble and Soluble Dietary Fiber in Food EnzymaticGravimetric Method, MES-TRIS Buffer. Official Methods of Analysis. 16th ed.Gaithersburg,MD : AOAC International.

AOAC 971.30. 1972.A-Tocopherol and aTocopheryl Acetate in Foods and Feeds Calarimetric Method. Official Methods of Analysis. Gaithersburg,MD : AOAC International.

Apriyantono A, Fardiaz D, Puspitasari NL, Yasni S, dan Budiyanto S. 1989. Analisis Pangan. Bogor : IPB Press.

Ball GMF. 1988. Fat Soluble Vitamin Assays in Food Analysis. London : Elsevier Science Publ. Ltd.

Hairunnisa O, Sulistyowati E, Suherman D. 2016. Pemberian kecambah kacang hijau (Tauge) terhadap kualitas fisik dan uji organoleptik bakso Ayam. Jurnal Sain Peternakan Indonesia. 11(1) : 39 -47.

Heiber I, Cai W, dan Baier M. 2014. Linking chloroplast antioxidant defense to carbohydrate availability: the transcript abundance of stromal ascorbate peroxidase is sugar-controlled via ascorbate biosynthesis. Molecular Plant. 7 (1) : 5870.

Hustiany R dan Mustikasari K. 2010. Karakterisasi dan fraksinasi produk bernilai protein tinggi dari kacang nagara dan tempe kacang nagara (Vigna unguiculata spp Cylindrica).
[Laporan Penelitian]. Banjarmasin : Universitas Lambung Mangkurat.

Hustiany R. 2015. Potential of nagara pea (Vigna unguiculata spp. Cylindrica) for Processed food of tempe. Prosiding Seminar Nasional Pangan, Pakan, dan Energi Terbarukan 2014. Yogyakarta. 221-227 21-23 Oktober 2014.

Hustiany R, Rahmawati E, dan Rahmi A. 2016. Development potential of nagara bean (Vigna unguiculata ssp. Cylindrica) cultivated in freshwater swamplands for processed food. Tropical Wetland Journal. $2(3): 30-36$.

Ismayanti M dan Harijono. 2015. Formulasi MPASI berbasis tepung kecambah kacang tunggak dan tepung jagung dengan metode linear programming. Jurnal Pangan dan Agroindustri. 3(3) : 996 - 1005.

Jean CCDA dan PGB Ranty. 2013. Calcium/calmodulin-mediated regulation of plant immunity. [Review] Biochimica et Biophysica Acta (BBA) - Molecular Cell Research. 1833 (7) : 1766-1771.

Ji CY, Y-H Kim, HS Kim, Q Ke, G-W Kim, S-C Park, H-S Lee, JC Jeong, S-S Kwak. 2016. Molecular characterization of tocopherol biosynthetic genes in sweetpotato that respond to stress and activate the tocopherol production in tobacco. Plant Physiology and Biochemistry. $106: 118-128$.

Khokhar Z, MA Athar, Q-A Syed, S Baig, M Nadeem, MG Sher, S Aliand I Islam. 2010. Studies on the Development of Value Added Food by Rhizopus Oligosporus in Koji Fermentation. Sci. Int. (Lahore). 22(3):219-226.

Kobayashi T, T Nozoye, NK Nishizawa. 2019. Iron transport and its regulation in plants. [Review Article]. Free Radical Biology and Medicine. 133 : 11-20.

Muchtadi D. 1993. Teknik Evaluasi Nilai Gizi Protein. Bogor : Ilmu Pangan, IPB.

Nollet LML. 1996. Handbook of Food Analysis, Amino Acid. Boca Raton : CRC Press.

Ntagkas N, Woltering EJ, dan Marcelis LFM. 2018. Light regulates ascorbate in plants: An integrated view on physiology and biochemistry.[Review]. Environmental and Experimental Botany.147 : 271-280.

Prangdimurti E, FR Zakaria, NS Palupi, S Koswara, PE Giriwono, A Hartoyo. 2013. Penuntun Praktikum Evaluasi Biologis Komponen Pangan. Bogor : Departemen Ilmu dan Teknologi Pangan. Institut Pertanian Bogor. ISBN 978-602-8122-25-2.

Pranoto HS, Mugnisjah WQ, dan Murniati E. 1990. Biologi Benih. Bogor : Pusat Antar Universitas, IPB. 
Rohmah M. 2012. Karakterisasi Sifat Fisikokimia Tepung dan Pati Pisang Kapas (Musa comiculata). Jurnal Teknologi Pertanian.8(1) : 20-24.

Salunkhe DK, Kadam SS, dan Chavan JK. 1985. Postharvest Biotechnology of Food Legumes. Boca Raton: CRC Press.

Saputro DH, Andriani MAM, dan Siswanti. 2015. Karakteristik sifat fisik dan kimia formulasi tepung kecambah kacang-kacangan sebagai bahan minuman fungsioanal. Jurnal Teknosains Pangan. 4(1) : 10 -19.

Shiroma S, Tanaka M, Sasaki T, Ogawa T, Yoshimura K, Sawa Y, Maruta T, Ishikawa T. 2019. Chloroplast development activates the expression of ascorbate biosynthesis-associated genes in Arabidopsis roots. Plant Science. 284: 185191.

Smirnoff N. 2018. Ascorbic acid metabolism and functions: A comparison of plants and mammals. [Review Article]. Free Radical Biology and Medicine. 122 : 116-129.

Srinivasan A, Vijayakumar S, Raman K, Srivastava S. 2019. Rational metabolic engineering for enhanced alpha-tocopherol production in Helianthus annuus cell culture. Biochemical Engineering Journal. $151: 107256$.

Utari DM, Rimbawan, Riyadi H, Muhilal, Purwantyastuti. 2011. Potensi asam amino pada tempe untuk memperbaiki profil lipid dan diabetes mellitus. Jurnal Kesehatan Masyarakat Nasional. 5(4) : 166 - 170.

Utomo JS, Kasno A, dan Wardani T. 2002. Nilai gizi dan prospek pengembangan kacang komak di lahan kering beriklim kering. Makalah Balittan Malang.91: SM-46.

Wang X, B Zhu, Z Jiang, S Wang. 2019. Calciummediation of jasmonate biosynthesis and signaling in plants. [Review Article) Plant Science. 287 : 110192.

Waters Corporation. 2012. Waters Acquity UPLC H Class and H Class Bio amino Acid Analysis System Guide. USA : Waters Corporation.

Wea ASY, Widodo R, dan Pratomo YA. 2014. Evaluasi kualitas produk susu kecambah kacang hijau, kajian umur kecambah dan konsentrasi Na-CMC. Jurnal Teknik Industri Heuristic. 11(1) : 61-79.

Windrati WS, Nafi A, dan Augustine PD. 2010. Sifat Nutrisional Protein Rich Flour (PRF) Koro Pedang (Canavalia ensiformis L.). Agrotek. 4(1) : $18-26$.

Yang X-Y, J-X Xie, F-F Wang, J Zhong, Y-Z Liu, G-H Li, S-A Peng. 2011. Comparison of ascorbate metabolism in fruits of two citrus species with obvious difference in ascorbate content in pulp. Journal of Plant Physiology.168 (18) : 2196-2205.

Yasa, IWS, Nazaruddin, dan Saloko S. 2009. Keefektifan Berbagai Jenis Tepung Kecambah Kacang meningkatkan mutu makanan sapihan tradisional. Mataram : Prosiding Seminar Nasional FTP UNUD 2009.

Zha L, Zhang Y, dan Liu W. 2019. Dynamic responses of ascorbate pool and metabolism in lettuce to long-term continuous light provided by red and blue LEDs. Environmental and Experimental Botany. $163: 15-23$. 